\title{
Shifts in soil microbial stoichiometry and metabolic quotient provide evidence for a critical tipping point at $1 \%$ soil organic carbon in an agricultural post-mining chronosequence
}

\author{
Jessica Clayton ${ }^{1} \cdot$ Kathleen Lemanski $^{1} \cdot$ Michael Bonkowski $^{1}$ (B) \\ Received: 17 August 2020 / Revised: 30 November 2020 / Accepted: 6 December 2020 / Published online: 16 January 2021 \\ (C) The Author(s) 2021
}

\begin{abstract}
Soil microbial C:N:P stoichiometry and microbial maintenance respiration (i.e. metabolic quotient, $\mathrm{qCO}_{2}$ ) were monitored along a nutrient gradient in soils from a 52-year space-for-time chronosequence of reclaimed agricultural land after brown-coal mining. Land reclamation produced loess soils of initially low $(0.2 \%)$ SOC. Consecutive agricultural land management led to a gradual recovery of SOC contents. Our data revealed sudden shifts in microbial stoichiometry and metabolic quotient with increasing SOC at a critical value of $1 \%$ SOC. As SOC increased, accrual rate of C into microbial biomass decreased, whereas microbial N increased. Simultaneously, metabolic quotient strongly decreased with increasing SOC until the same critical value of $1 \%$ SOC and remained at a constant low thereafter. The microbial fractions of the soil in samples containing $<1 \%$ SOC were out of stoichiometric equilibrium and were inefficient at immobilising $\mathrm{C}$ due to high maintenance respiration. Increasing SOC above the threshold value shifted the soil microbes towards a new equilibrium where $\mathrm{N}$ became growth limiting, leading to a more efficient acquisition of $\mathrm{C}$. The shift in microbial $\mathrm{N}$ accrual was preluded by high variation in microbial biomass $\mathrm{N}$ in soils containing $0.5-$ $0.9 \%$ SOC indicative of a regime shift between microbial stoichiometric equilibria. Our data may help in establishing a quantitative framework for SOC targets that, along with agricultural intensification, may better support feedback mechanisms for a sustainable accrual of $\mathrm{C}$ in soils.
\end{abstract}

Keywords Microbial stoichiometry $\cdot$ Metabolic quotient $\cdot$ Tipping point $\cdot$ Soil organic carbon $\cdot$ Stoichiometry

\section{Introduction}

Chronosequences of post-mining areas are ideal model systems to study soil processes related to the formation of soil organic matter (SOM) over time, because these soils, typically being reclaimed over decades from the same carbon-poor overburden substrates, form a succession of soil development with almost identical starting conditions and well-defined dates of origin (Bartuska and Frouz 2015; Dworschak and Rose 2014; Walker et al. 2010). As SOM content is linked to crop yield through its nutrient content and water retention in soil (Oldfield et al. 2019), it is important to gain a deeper understanding of the mechanisms promoting $\mathrm{C}$ sequestration in agricultural soils (Singh et al. 2018). Agricultural

Michael Bonkowski

m.bonkowski@uni-koeln.de

1 Institute of Zoology, Terrestrial Ecology, University of Cologne, Zülpicher Strasse 47b, 50674 Cologne, Germany management, however, too often promotes $\mathrm{C}$ depletion of SOM (Liu et al. 2010; Panettieri et al. 2014; Paustian et al. 2004), while these soils instead could represent a globally important C sink (Chabbi et al. 2017; Minasny et al. 2017; Poulton et al. 2018). Traditionally, the build-up and persistence of soil organic $\mathrm{C}$ (SOC) were thought to depend on the chemical 'recalcitrance' of plant inputs to decomposition, yet recent research provides compelling evidence for microbial necromass as the main contributor to the stable SOM fraction in soils (Kallenbach et al. 2015, 2016; Miltner et al. 2012; 2009). It is now thought that, after microbial death, with each iterative turnover of the microbial community, a fraction of its necromass is stabilised by the mineral soil matrix, leading to a gradual accrual of SOC (Chenu and Stotzky 2002; KögelKnabner et al. 2008; Liang et al. 2017). This theory implies a reconsideration of the build-up and maintenance of soil carbon stocks, which requires a better understanding and management of soil microbial biomass (Fang et al. 2020; Kallenbach et al. 2015, 2016; Khan and Joergensen 2019; Kirkby et al. 2013). 
Ecological stoichiometry sets physiological constraints on the incorporation of $\mathrm{C}$ and other nutrients into microbial biomass (Marklein and Houlton 2012; Mooshammer et al. 2014; Sinsabaugh et al. 2009; Sinsabaugh and Moorhead 1994), and provides a compelling framework for the management of SOC (Buchkowski et al. 2019; Hessen et al. 2004). However, the regulation of the build-up and maintenance of microbial biomass in soils is still not well understood. Generally, microbial biomass C (MB-C) grows linear with increasing SOC content (Anderson and Domsch 1989), but microbial biomass $\mathrm{N}(\mathrm{MB}-\mathrm{N})$ and $\mathrm{P}$ (MB-P) may not grow at the same rate, leading to stoichiometric mismatch between microbial consumer and resource (Khan and Joergensen 2019; Mulder et al. 2013). Soil microorganisms can respond to such a stoichiometric imbalance by either adjusting their stoichiometry to match the resource (plasticity) or by maintaining a fixed stoichiometry (homeostasis) (Spohn 2016). Both require adaptations on the individual level, e.g. by expelling or storing nutrients (Manzoni and Porporato 2009) and adjusting exoenzyme production (Allison and Vitousek 2005; Sinsabaugh et al. 2009), and/or on the community level through shifts in community composition to species that are better adapted to the constraints of the resource (Ma et al. 2019; ZechmeisterBoltenstern et al. 2015). However, a consensus on the stoichiometric plasticity of soil microbial biomass and a good mechanistic understanding of the factors driving the relationship between soil and microbial stoichiometry have not yet been reached (Cleveland and Liptzin 2007; Ehlers et al. 2010; Fanin et al. 2017; 2013; Hartman and Richardson 2013; Li et al. 2012; Xue et al. 2019).

In contrast to aquatic systems, nutrients in soil are mostly bound to organic matter and only a fraction is freely accessible to microorganisms (Griffiths et al. 2012). This transient availability of readily accessible $\mathrm{C}$ substrates is the main limiting factor for microbial activity in soils (Demoling et al. 2007; Kaiser 1994; Kamble and Bååth 2014; Kuzyakov and Blagodatskaya 2015). As a result of this, the vast majority of soil microbiome remains in a dormant state most of the time while maintaining only basic metabolic processes (Blagodatskaya and Kuzyakov 2013; Joergensen and Wichern 2018).

The specific metabolic quotient $\left(\mathrm{qCO}_{2}\right)$, typically given as the ratio of basal $\mathrm{C}$ respiration rate (respired $\mathrm{CO}_{2}$ ) to unit biomass $\mathrm{C}(\mathrm{MB}-\mathrm{C})$, measures the energy required for the long-term maintenance of the microbial biomass in soils ('maintenance respiration'; Anderson and Domsch 1985a, 1985b). Stoichiometric imbalance requires higher maintenance respiration (Griffiths et al. 2012) and can lead to a gradual decline of soil microbial biomass if $\mathrm{C}$ is not sufficiently supplied (Anderson and Domsch 1985a; Blagodatsky and Richter 1998; Joergensen and Wichern 2018). Still, the relationship between soil stoichiometry and maintenance respiration is not well explored. The metabolic quotient $\left(\mathrm{qCO}_{2}\right)$ is a measure of the fundamental physiological state of the microbial community. It is influenced by the fungal to bacterial biomass ratio in soils (Nannipieri et al. 2003; Sakamoto and Oba 1994) and has been widely used as an indicator of change in the eco-physical status of soil microorganisms (Anderson and Domsch 2010), for example during succession (Insam and Domsch 1988; Insam and Haselwandter 1989), land use change (Hartman and Richardson 2013; Xu et al. 2017) or due to soil management (Zhou et al. 2017) and disturbance (Insam et al. 1996; Odum 1985).

In this study, we investigated changes in microbial stoichiometry and metabolic quotient along a soil nutrient gradient of a post-mining agricultural chronosequence, formed from the reclaimed land of the open-cast brown-coal mine Inden, North Rhein-Westphalia, Germany. Homogeneous agricultural loess soils have been restored in this region according to a standardised process for over 50 years (Dworschak and Rose 2014; Pihlap et al. 2019; Lucas et al. 2019), forming an ideal space-for-time substitution (Pickett 1989; Walker et al. 2010) for the study of stoichiometric changes during soil development after restoration. We studied both the cultivated arable fields and their arable margins (grass strips directly bordering the arable fields), because we expected the unmanaged margins would have higher SOM contents due to the lack of ploughing nor regular removal of plant biomass. Half a century of soil development since restoration has given rise to a SOM gradient along the chronosequence, ranging from SOCpoor freshly deposited young soils to the more developed arable soils after 52 years of cultivation with maximum SOC content in arable margins.

We hypothesised that (1) soil microbial biomass in the chronosequence soils would not follow strict homeostasis; (2) soil microbes would be in a state of stoichiometric imbalance in young, nutrient-poor soils; (3) soil microbial stoichiometry will gradually converge to an optimum ratio with increasing age/SOM content; and (4) the metabolic quotient $\left(\mathrm{qCO}_{2}\right)$ will be high in soils with stoichiometric imbalance and would decrease as optimum ratio is reached.

\section{Materials and methods}

\section{Formation of chronosequence soils}

The study was conducted in a 52-year post-mining agricultural chronosequence near Inden, Germany ( $50^{\circ} 52^{\prime} 44.6^{\prime \prime} \mathrm{N} 6^{\circ} 19^{\prime}$ 04.4"E; Fig. S1). Mean annual temperature is $9.8^{\circ} \mathrm{C}$ and the mean annual precipitation is $829 \mathrm{~mm}$. The mining company RWE Power AG (Essen, Germany) extracted lignite from the earth via open-cast mining. This involves completely removing the topsoil and subjacent layers of tertiary sands to a depth of $>100 \mathrm{~m}$ in order to expose the lignite seam beneath. After lignite has been extracted, the cavity is filled again with the 
material which was previously removed. The process of extraction and restoration is continuous as the mining company follow the lignite seam. Large conveyor belts continuously transport material from the front of the mine (where excavation proceeds) to the back of the mine (where exaction has ended) to refill the cavity and restore the land to its previous usage. This has given rise to a $>50$-year chronosequence of restored agricultural soils, whereby the restored soils closest to the mine are the youngest and those further away increase in age. The reclamation process has hardly changed in decades (Dumbeck 1992, Dworschak and Rose 2014). RWE has kept detailed records of the mine's trajectory through the landscape and the dates of when the land was restored. At the front of the mine, diggers first remove the top soil loess layer, occasionally reaching down to $12 \mathrm{~m}$ depth, and carefully separate it from deeper substrate layers of tertiary sands. Then, the loess and sandy substrates are each separately mixed and moved by conveyor belts to fill up the backside of the mine, where on top of the tertiary sands a 2-m layer of homogenised loess (containing 1\% former topsoil, $0.2 \%$ SOC) is evenly spread (Dworschak and Rose 2014). The ceaseless process creates a continuum of very homogeneous but successively older agricultural loess soils, while the open-cast mine continues to advance through the landscape.

\section{Management of reclaimed land after mining}

Reclaimed soils typically received in the first year an initial fertilisation of 60,120 and $180 \mathrm{~kg} \mathrm{ha}^{-1}$ of N, P and K fertiliser respectively, and are cultivated for three subsequent years with alfalfa (Medicago sativa) without any further fertiliser or biocide applications. Four to 7 years after reclamation, fields typically undergo a wheat and barley crop rotation. Cereals are fertilised by NPK and CAN (calcium ammonium nitrate) mineral fertilisers, and receive in addition in the fourth and seventh year of reclamation $30 \mathrm{t} \mathrm{ha}^{-1}$ of organic fertiliser (compost), resulting in a total annual fertilisation rate of 200, 80, 60 and $40 \mathrm{~kg} \mathrm{ha}^{-1}$ of $\mathrm{N}, \mathrm{P}, \mathrm{K}$ and $\mathrm{Mg}$ fertiliser, respectively. After 7 years, fields are returned to the previous owners and are usually managed with a sugar beet-winter wheat crop rotation. The perimeters of the arable fields were left unmanaged and are only between 20 and $100 \mathrm{~cm}$ wide. These strips we here name 'arable margins'. They differ only in that they were not intensively cultivated, i.e. had a continuous grass cover and were seldomly ploughed. Due to their narrow width, we assume that the arable margins received the same mineral fertiliser input as the arable fields. Minimum sampling distance between arable field and arable margin soils was $10 \mathrm{~m}$ (Fig. S2).

\section{Soil sampling}

Soil sampling took place in March 2016 in ten sites of ages 1, $2,3,4,5,10,26,37,45$ and 52 years after reclamation at the time of sampling. The location of sampling sites was determined by the exact recordings of the former locations of the mine (Fig. S1). Most sampling sites were less than $3000 \mathrm{~m}$ apart and the maximum distance between sampling sites was $6000 \mathrm{~m}$. At each site, soil was sampled from the reclaimed arable field and from the arable margins directly bordering the arable fields (factor 'soil origin'). Information on the crop growing at time of sampling can be found in the supplementary material (Table S1). Per field, five technical replicates, each consisting of five pooled soil cores $(6 \mathrm{~cm} \varnothing$, with a depth of $10 \mathrm{~cm}$ ), were collected (for more details, see Roy et al. (2017)). At the adjacent arable margins, three technical replicates consisting each of two soil cores were sampled. All samples were sieved $(2 \mathrm{~mm})$, roots and stones removed, and stored at $4{ }^{\circ} \mathrm{C}$ prior to analysis.

\section{Measurement of soil nutrients, microbial stoichiometry and microbial respiration}

Soil organic $\mathrm{C}$ (SOC) was measured after the removal of inorganic $\mathrm{C}$ by addition of $10 \% \mathrm{HCl}$ (Nelson and Sommers 1996) and determined by combustion together with total soil $\mathrm{N}\left(\mathrm{N}_{\text {tot }}\right)$ using a C/N element analyser (Flash 2000 Thermo Fisher Scientific GmbH, Germany). Soil extractable P was measured using the calcium-lactate extraction method (Schüller 1969).

Soil microbial biomass C (MB-C) and N (MB-N) were determined via the chloroform fumigation-extraction (CFE) method (Vance et al. 1987) using the respective extraction constants for $\mathrm{C}$ and $\mathrm{N}, k_{\mathrm{EC}}=0.45$ and $k_{\mathrm{EN}}=0.54$ (Joergensen 1996; Wu et al. 1990). Samples were shaken with $0.5 \mathrm{M} \mathrm{K}_{2} \mathrm{SO}_{4}$ on a platform shaker for $30 \mathrm{~min}$ (1:4 soil:extractant ratio) to extract available $\mathrm{C}$ and $\mathrm{N}$ (soil extractable $\mathrm{C}(\mathrm{Cext})$ and $\mathrm{N}(\mathrm{Next})$ ). Extracts were frozen until measurement with a Multi N/C 2100S (Analytik Jena, Germany). Soil microbial P (MB-P) was determined using a modified anion exchange membrane method (Kouno et al. 1995; Myers et al. 1999) using hexanol instead of chloroform to induce cell lysis (Clausing et al. 2020). P concentration in the extracts was measured using the Murphy and Riley colorimetric test (Murphy and Riley 1962) with a microplate reader (photometric wavelength 710, Varioskan ${ }^{\mathrm{TM}}$, Thermo Electron Corporation, Germany). Some extracts for MB-C/MB-N analysis were lost during failure of the Multi N/C analyser, resulting in unequal numbers of replicates between sites.

The metabolic quotient $\left(\mathrm{qCO}_{2} ; \mathrm{CO}_{2}-\mathrm{C}\right.$ mmol MB-C $\mathrm{mol}^{-1} \mathrm{~h}^{-1}$ ) was calculated as the microbial basal respiration to unit microbial biomass C (MB-C). Microbial basal respiration was measured over $24 \mathrm{~h}$ with a micro-compensation apparatus (Scheu 1992). Prior to measurement, fresh soil with $3 \mathrm{~g}$ equivalent dry soil were adjusted to $50 \%$ water holding capacity and incubated overnight at $20^{\circ} \mathrm{C}$. Respiration rates were converted from $\mathrm{O}_{2}$ consumption to $\mathrm{CO}_{2}$ - $\mathrm{C}$ respired using the ideal gas constant (e.g. $1 \mu \mathrm{l} \mathrm{O} 2 \sim 12 / 22.4=0.53 \mu \mathrm{g} \mathrm{CO}_{2}-\mathrm{C}$ ). 


\section{Statistical analyses}

Non-linear shifts in microbial nutrient accrual and metabolic quotient $\left(\mathrm{qCO}_{2}\right)$ with increasing SOC were revealed by breakpoint analysis. Data were subsequently $\ln (x+1)$ transformed for linearity and subset into two groups by a soil nutrient content grouping variable with two factors (soil nutrient content either above or below a critical value). Segmented regression was performed on the subset data to give individual slopes for the two groups. To determine whether the two slopes of the segmented regressions were significantly different from the slopes where no grouping criteria were applied, an ANCOVA analysis was performed (linear model with grouping variable interaction). All statistical analyses were conducted in R (version 3.5.0) using the base and stats packages (R Core Team 2018). The segmented function in the package segmented was used to calculate breakpoints in the data (Muggeo 2008). Other R packages used for graphing and data handling include ggplot2 (Wickham 2016), dplyr (Wickham et al. 2018), tidyr (Wickham and Henry 2018), lattice (Sarkar 2008) and latticeExtra (Sarkar and Andrews 2019).

\section{Results}

\section{Development of soil nutrients and microbial stoichiometry over time after restoration}

Changes in soil nutrient levels ( $\mathrm{SOC}$, total $\mathrm{N}$, extractable $\mathrm{P}$ ) and microbial biomass (MB-C, MB-N, MB-P) followed a similar pattern with increasing age after restoration (Fig. S3a-f). Initially, soil nutrients and microbial biomass increased at the same rate in both arable and arable margins in soils aged $1-5$ years. After 10 years, the accumulation of SOC and microbial biomass ceased in the arable soils, but continued to increase in the margin soils (Fig. S1a-e). SOC ranged between 0.21 and $0.93 \%$ in arable soils and between 0.22 and $4.47 \%$ in the margin soils.

Plotting the ratios of soil $\mathrm{C}: \mathrm{N}$ versus microbial biomass $\mathrm{C}: \mathrm{N}$ (MB-C:N) with the soil C:N calculated either from SOC and total N (SOC: $\mathrm{N}_{\text {tot }}$ ) or from the extractable $\mathrm{C}$ and $\mathrm{N}$ $\left(\mathrm{C}_{\text {ext }}: \mathrm{N}_{\text {ext }}\right)$ (Fig. 1a, b) showed slopes strongly deviating from the 1:1 line (where microbial $\mathrm{C}: \mathrm{N}$ is exactly balanced by the $\mathrm{C}: \mathrm{N}$ of the soil resource). Generally, variation in MB-C:N relative to soil stoichiometry was high in young soils and decreased with soil age, indicating a progressively constrained stoichiometry within the soil microbial community with increasing soil age after recultivation. In particular, the changes in microbial $\mathrm{C}: \mathrm{N}$ relative to extractable soil $\mathrm{C}: \mathrm{N}$ appeared vertically directed towards the $1: 1$ line as indicated by significant linear relationships in soils aged 4,10 and 26 years after recultivation (Fig. 1b). In soils aged $>26$ years, the slopes decreased and the values converged close to the 1:1 line within a narrow range of extractable soil C:N $\left(\mathrm{C}_{\text {ext }}: \mathrm{N}_{\text {ext }}\right)$. This was true for both arable and margin soils, despite significant differences in total amounts of C and N (Fig. S3a-b). We calculated the final microbial $\mathrm{C}: \mathrm{N}$ ratio as the MB-C:N values where the slope crossed the 1:1 line in soils aged 37, 42 and 52 years; these were $4.4,4.6$ and 5.6 respectively.

\section{Microbial biomass accumulation as a function of SOM}

Nutrient contents of soil microbial biomass generally increased with increasing SOC content. However, the rate of increase in MB-C and MB-N was not constant with increasing SOC (Fig. 2) due to shifts in microbial stoichiometry around a threshold value of $810 \mathrm{mmol} \mathrm{kg}^{-1} \mathrm{SOC}(\sim 1 \%$ SOC). In soils containing $<810 \mathrm{mmol} \mathrm{kg}^{-1}$ SOC, MB-C increased strongly with increasing SOC (slope $\mu 1=1.2$; Table 1). Above this threshold, accrual rate of MB-C decreased by $50 \%$ MB-C compared to the soils below the threshold (slope $\mu 2=0.58$; Table 1). Conversely, increasing SOC content had the opposite effect on microbial $\mathrm{N}$ accumulation (Fig. 2). There was a weak accumulation of MB-N with increasing SOC in soils containing $<450 \mathrm{mmol} \mathrm{kg}^{-1}$ SOC (slope $\mu 3=0.48$; Table 1), whereas above the critical value of $810 \mathrm{mmol} \mathrm{kg}{ }^{-1}$ SOC, microbial $\mathrm{N}$ accumulation rate doubled (slope $\mu 4=$ 0.81 ; Table 1). The shift in microbial $\mathrm{N}$ accrual was preluded by a region of high variance within $\mathrm{MB}-\mathrm{N}$ in soils containing 450-700 mmol kg-1 SOC (0.5-0.9\% SOC). Microbial P (MB-P) increased gradually with SOC (slope $\mu 5=0.31$; Table 1) and no shift in $P$ accrual rate was observed. Soil total $\mathrm{N}\left(\mathrm{N}_{\text {tot }}\right)$ was strongly correlated to SOC (Fig. S4); therefore, when MB-N was plotted as a function of $\mathrm{N}_{\text {tot }}$ (Fig. 3), a similar shift in MB-N was observed. Here, the shift to increased accrual rate of MB-N (slope $\mu 7=1.03$; Table 1) occurred at a critical value of $32 \mathrm{mmol} \mathrm{kg}^{-1} \mathrm{~N}_{\text {tot }}\left(\sim 0.045 \% \mathrm{~N}_{\text {tot }}\right)$.

Parallel to the shifts in accrual rate of MB-C and MB$\mathrm{N}$, there was also a shift in the relationship of metabolic quotient $\left(\mathrm{qCO}_{2}\right)$ to $\mathrm{SOC}$ at the same critical value of $810 \mathrm{mmol} \mathrm{kg}{ }^{-1}(\sim 1 \%)$ SOC (Fig. 4). $\mathrm{qCO}_{2}$ decreased log-linearly with increasing SOC until the critical value (slope $\mu 8=-0.72$; Table 1 ); above the critical value, $\mathrm{qCO}_{2}$ remained at a low level of $4.46 \pm 1.26\left(\mathrm{CO}_{2}-\mathrm{C}\right.$ $\mathrm{mmol} \mathrm{h}{ }^{-1} \mathrm{MB}-\mathrm{C} \mathrm{mol}{ }^{-1}$ ) independent of increasing SOC.

\section{Discussion}

In the recultivation chronosequence, the relationships of microbial C:N ratio to soil $\mathrm{C}: \mathrm{N}$ ratio were driven by soil age after recultivation (Fig. 1a, b). Values above the 1:1 line indicate $\operatorname{good} \mathrm{N}$ availability due to a narrow soil C:N relationship. Yet the microbial biomass was characterised by surprisingly high $\mathrm{C}: \mathrm{N}$ ratios, especially in soils aged $<10$ years (Fig. 1a, b). 

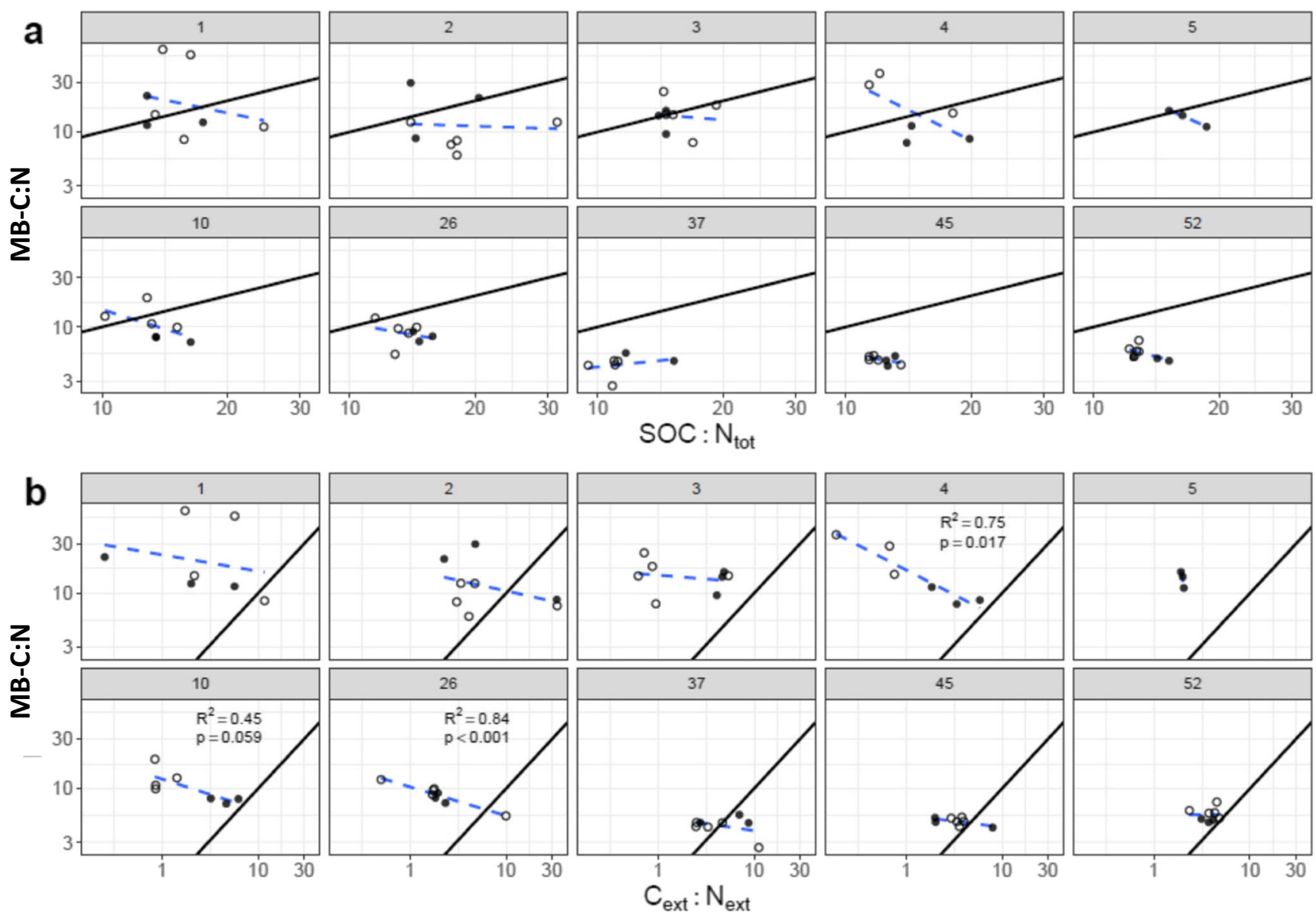

Fig. 1 Scatter plots and slopes (dashed line) of a molar soil total C:N ratio (SOC: $\mathrm{N}_{\text {tot }}$ ) versus molar microbial biomass $\mathrm{C}: \mathrm{N}$ ratio $(\mathrm{MB}-\mathrm{C}: \mathrm{N})$ and $\mathbf{b}$ molar available $\mathrm{C}: \mathrm{N}$ ratio from extractable $\mathrm{C}$ and $\mathrm{N}\left(\mathrm{C}_{\text {ext }}: \mathrm{N}_{\text {ext }}\right)$ versus molar microbial biomass $\mathrm{C}: \mathrm{N}$ ratio (MB-C:N) in soils of different ages

(1-52 years) after recultivation for arable field (filled circle) and arable margin (open circle). Values are shown in comparison to the 1:1 (solid) line. Adjusted $R^{2}$ and $p$ values are given in case of significant linear relationships

These young soils showed the largest differences between microbial and resource (soil) $\mathrm{C}: \mathrm{N}$ ratio, demonstrating a substantial stoichiometric imbalance. According to high MBC:N, Pihlap et al. (2019) assumed N limitation of microorganisms by investigating young reclaimed soils of the Garzweiler chronosequence with roughly comparable loess substrates in $50 \mathrm{~km}$ distance of our sites. With increasing soil age, variation in microbial stoichiometry decreased as microbial C:N converged towards the $1: 1$ relationship with soil $\mathrm{C}: \mathrm{N}$, pointing to a weak homeostatic regulation of microbial $\mathrm{C}: \mathrm{N}$ in these soils (Scott et al. 2012). Since total SOC and soil N are not immediately accessible to microorganisms, the extractable $\mathrm{C}$ and $\mathrm{N}$ give a much better approximation of the potentially available resources in soil (Griffiths et al. 2012). The (linear) convergence of microbial C:N towards the 1:1 line (Fig. 1b) clearly shows that the microbes better adjust to the available resource $\left(\mathrm{C}_{\text {ext }}: \mathrm{N}_{\text {ext }}\right)$ rather than to the total resource $\left(\mathrm{SOC}: \mathrm{N}_{\text {tot }}\right)$ stoichiometry, irrespective of soil origin being arable or arable margin. Our estimation of MB-C:N in soils aged 37-52 years was approximately $5: 1$, which is lower than the global average as reported by Cleveland and Liptzin (2007) but well within range of previously reported microbial biomass $\mathrm{C}: \mathrm{N}$ values for agricultural fields (Kallenbach and Grandy 2011). It shows that stoichiometric imbalance was a strong driver to balance soil microbial communities towards equilibrium with soil stoichiometry.

There is intensive discussion about the extent of variation in soil microbial stoichiometry and the factors driving it (Cleveland and Liptzin 2007; Fanin et al. 2017; 2013; Hartman and Richardson 2013; Li et al. 2012; Xue et al. 2019). Changes of the homogeneous soil substrate along the chronosequence revealed regular stoichiometric patterns of alterations in soil and microorganisms, which enable a better mechanistic understanding of the processes underlying variation in microbial stoichiometry and the associated formation of SOC.

\section{Critical thresholds in microbial stoichiometry}

Variation in microbial stoichiometry was not random. The much higher accrual rate (slope) of MB-C in soils with low SOC content in comparison to the accrual of MB-N and MB-P 
Table 1 Table of segmented regression statistics and ANCOVA model results for individual slopes $\mu 1-\mu 9$ of Figs. 2, 3 and 4 . All variables were $\ln (x+1)$ transformed for linearity. Microbial biomass C (MB-C), N (MB$\mathrm{N})$ and $\mathrm{P}(\mathrm{MB}-\mathrm{P})$ and metabolic quotient $\left(\mathrm{qCO}_{2}\right)(y$ variables in Figs. 2, 3 and 4) were modelled as a function of soil organic carbon (SOC) or soil total nitrogen $\left(\mathrm{N}_{\text {tot }}\right)(x$ variables in Figs. 2, 3 and 4). Wherever a critical threshold in $x$ or $y\left(x_{\mathrm{c}}\right.$ or $\left.y_{\mathrm{c}}\right)$ was identified via breakpoint analysis, the data were subset into two groups: e.g. $x<=x_{\mathrm{c}}$ and $x>x_{\mathrm{c}}$. Segmented linear regression was carried out on the subset data, resulting in two slopes per $x y$ variable pair. To determine whether the two slopes of the segmented regressions were significantly different from the slopes where no grouping criteria were applied, an ANCOVA analysis was performed (linear model with grouping variable interaction). All ANCOVA models showed a significant difference to the model without grouping variable interaction (confidence interval, $p<0.01$ ). ANCOVA results shown in the table are from the regression model including grouping variable. Significance levels: $p<0.1(*) ; p<0.05(*), p<0.001(* * *)$

\begin{tabular}{|c|c|c|c|c|c|c|c|c|c|c|c|c|c|}
\hline \multirow[b]{2}{*}{ Slope ref. } & \multirow[b]{2}{*}{ Fig. ref. } & \multicolumn{8}{|c|}{ Linear regression of $\ln (x+1)$ transformed data subset according to the breakpoint } & \multicolumn{4}{|c|}{ ANCOVA } \\
\hline & & $x$ & $y$ & $n$ & $R^{2}$ & Slope & Intercept & Significance & Critical value (variable, $\mathrm{mmol} \mathrm{kg}^{-1}$ ) & $R^{2}$ & $F$ & $d f$ & Sig \\
\hline$\mu 1$ & 2 & SOC & MB-C & 67 & 0.88 & 1.20 & -4.85 & $* * *$ & $\mathrm{SOC} \leq 810$ & 0.93 & 537.4 & {$[3,75]$} & $* * *$ \\
\hline$\mu 2$ & 2 & SOC & MB-C & 12 & 0.61 & 0.58 & -0.27 & $* *$ & SOC $>810$ & & & & \\
\hline$\mu 3$ & 2 & SOC & MB-N & 39 & 0.59 & 0.48 & -2.31 & $* * *$ & $\mathrm{MB}-\mathrm{N} \leq 1.0$ & 0.95 & 390.2 & {$[3,67]$} & $* *$ \\
\hline$\mu 4$ & 2 & SOC & MB-N & 32 & 0.83 & 0.81 & -3.74 & $* * *$ & MB-N $>1.0$ & & & & \\
\hline$\mu 5$ & 2 & SOC & MB-P & 46 & 0.74 & 0.31 & -1.69 & $*$ & N/A & N/A & N/A & N/A & N/A \\
\hline$\mu 6$ & 3 & $\mathrm{~N}_{\text {tot }}$ & MB-N & 33 & 0.09 & 0.17 & -0.13 & ns & $\mathrm{N}_{\text {tot }} \leq 32$ & 0.91 & 261.60 & {$[3,75]$} & $* * *$ \\
\hline$\mu 7$ & 3 & $\mathrm{~N}_{\text {tot }}$ & MB-N & 39 & 0.85 & 1.03 & -2.73 & $* * *$ & $\mathrm{~N}_{\text {tot }}>32$ & & & & \\
\hline$\mu 8$ & 4 & SOC & $\mathrm{qCO}_{2}$ & 62 & 0.53 & -0.72 & 6.70 & $* * *$ & $\mathrm{SOC} \leq 810$ & 0.63 & 42.57 & {$[3,69]$} & $* *$ \\
\hline$\mu 9$ & 4 & SOC & $\mathrm{qCO}_{2}$ & 11 & 0.03 & 0.09 & 0.95 & ns & SOC $>810$ & & & & \\
\hline
\end{tabular}

(Fig. 2) reflects a higher microbial demand for $\mathrm{C}$ than $\mathrm{N}$ and $\mathrm{P}$ (Mulder et al. 2013). The most limiting element, C, showed a strong increase in microbial biomass with increasing SOC relative to the other elements until a critical threshold (1\% $\mathrm{SOC})$, where microbial stoichiometry was characterised by decreasing $\mathrm{C}$ and increasing microbial $\mathrm{N}$ demand (Fig. 2). Well-developed soils function as a slow-release fertiliser, where nutrients bound to SOM are gradually released upon mineralisation by extracellular enzymes (Sanderman et al. 2017). This buffering pool of $C$ and nutrients was however largely lacking in the SOM-poor, less-developed agricultural soils. Farrell et al. (2014) demonstrated that under such conditions microbial uptake of dissolved N-containing lowmolecular-weight molecules, such as peptides and amino acids, is primarily driven by microbial $\mathrm{C}$ demand rather than $\mathrm{N}$ demand. As soil organic $\mathrm{C}$ and $\mathrm{N}$ content increased above
Fig. 2 Accrual of C (MB-C), N (MB-N) and P (MB-P) in microbial biomass $\left(\mathrm{mmol} \mathrm{kg}^{-1}\right)$ with increasing soil organic $\mathrm{C}$ (SOC, mmol kg ${ }^{-1}$ ) in arable field soils (circles) and bordering arable margin soils (triangles). Data were $\ln (x+1)$ transformed and segmented linear regression was applied. See Table 1 for regression statistics. Upper $x$-axis SOC unit given in \%

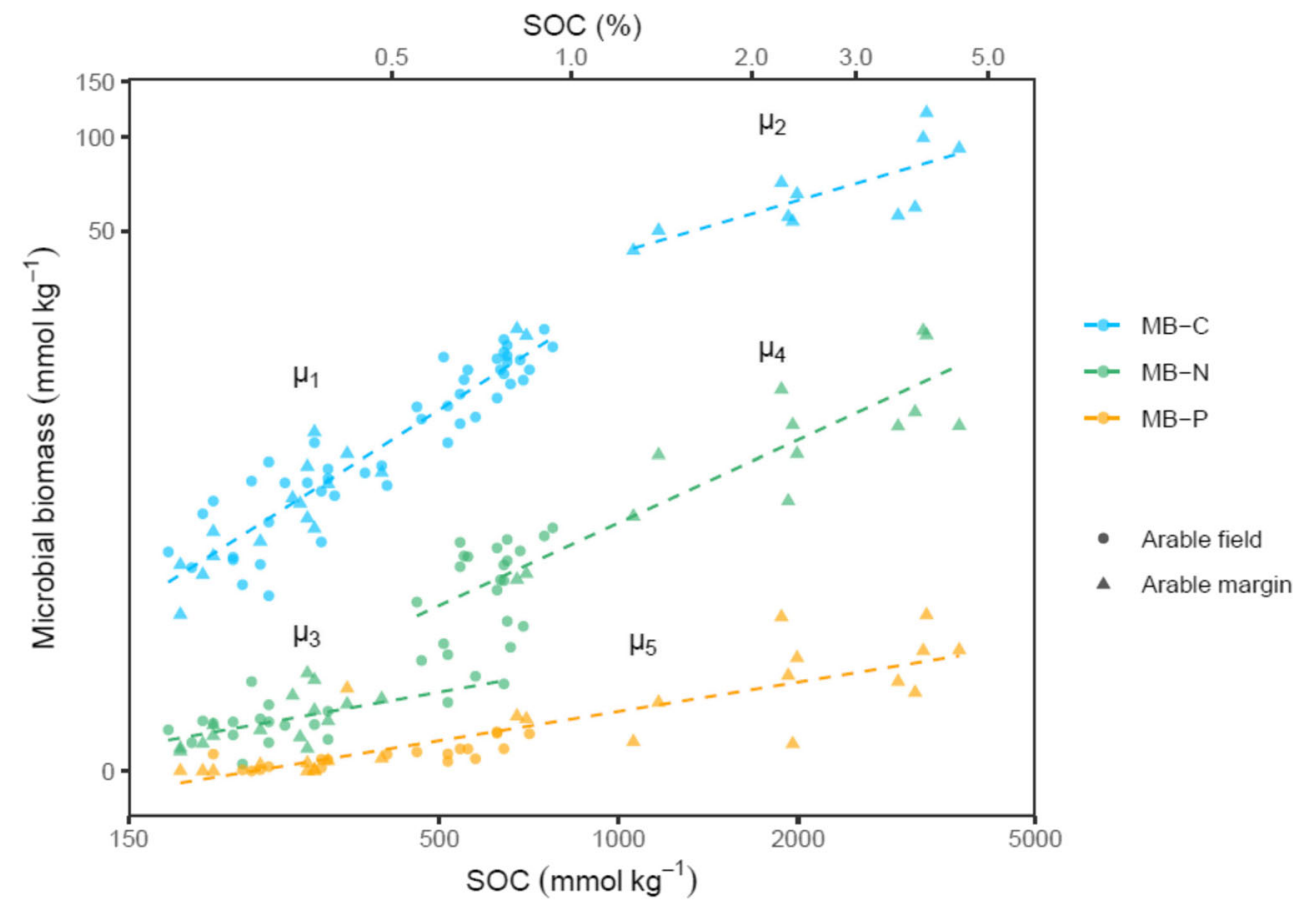


Fig. 3 Accrual of microbial biomass $\mathrm{N}(\mathrm{MB}-\mathrm{N})$ as a function of soil total $\mathrm{N}\left(\mathrm{N}_{\text {tot }}\right)$ in arable field soils (circles) and bordering arable margin soils (triangles). Data were $\ln (x+1)$ transformed for normality and segmented linear regression was applied. See Table 1 for regression statistics

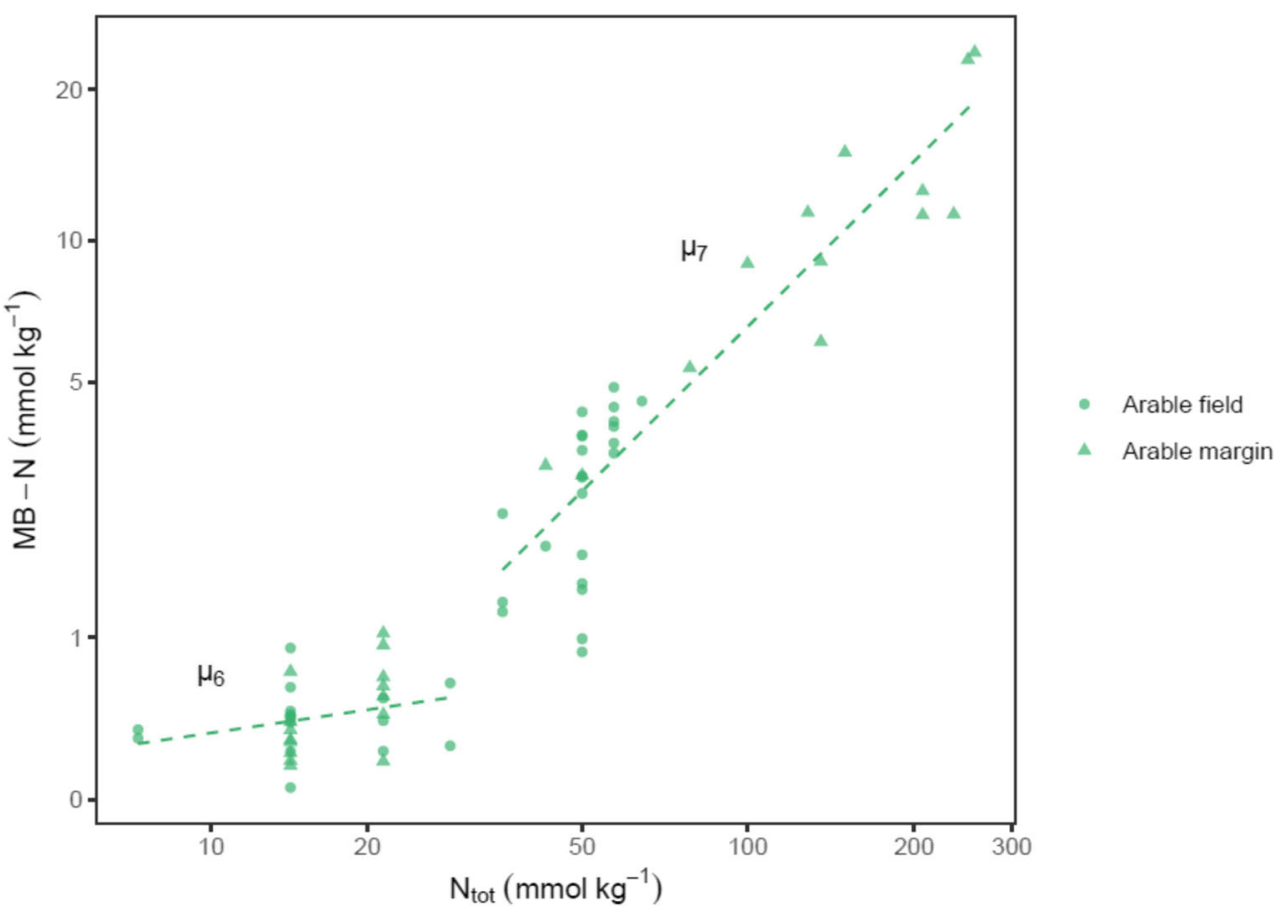

the critical value, the stoichiometric demands of the microbes could be better satisfied, as shown by the increased assimilation rate of $\mathrm{N}$ into microbial biomass with increasing SOM (slope $\mu 4$; Fig. 2). This demonstrates a shift from principal $\mathrm{C}$ limitation below the critical value, to microbial co-limitation of $\mathrm{C}$ and $\mathrm{N}$ above, where $\mathrm{N}$ became the next growth-limiting nutrient after C (Ma et al. 2019; Traoré et al. 2015). The accrual of $\mathrm{C}, \mathrm{N}$ and $\mathrm{P}$ into microbial biomass with increasing SOM follows exactly the same pattern in both arable and margin soils until $1 \%$ SOC, but only margin soils that surpass $1 \%$ SOC show a sudden decrease in the accrual rate of MB-C and an increase in the accrual rate of MB-N.

\section{High microbial maintenance respiration due to stoichiometric imbalance}

A parallel shift in $\mathrm{qCO}_{2}$ occurred at the same critical $1 \% \mathrm{SOC}$ value and revealed high respiratory $\mathrm{C}$ losses below the
Fig. 4 The metabolic quotient $\left(\mathrm{qCO}_{2}\right)$ as a function of soil organic C (SOC) content in arable field soils (circles) and bordering arable margin soils (triangles). Data were $\ln (x+1)$ transformed for normality and segmented linear regression was applied. See Table 1 for regression statistics. Upper $x$-axis SOC unit given in \%

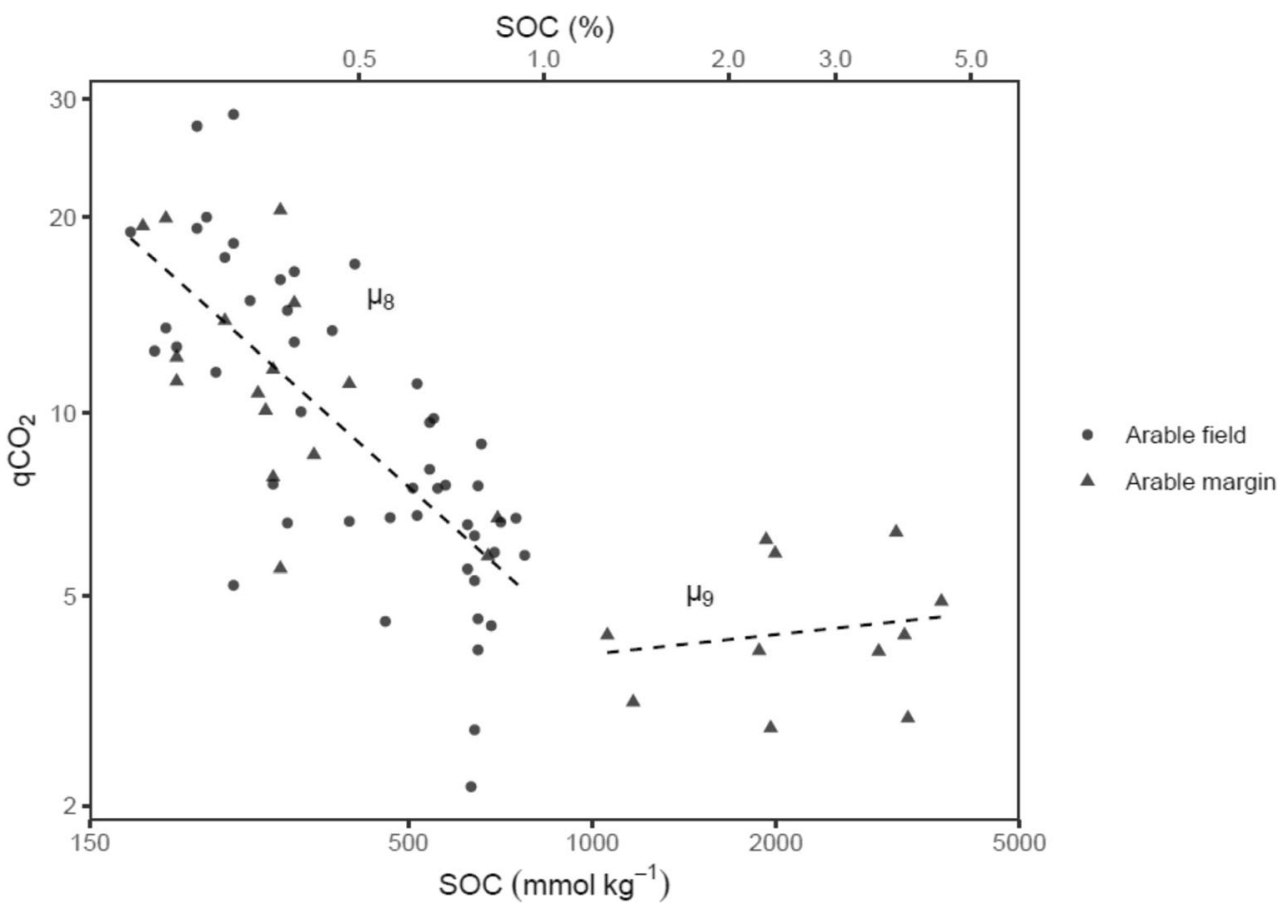


threshold, indicating stoichiometric imbalance of the microbial community (Schimel and Weintraub 2003; Sinsabaugh et al. 2013, 2016). In soils containing less than $1 \%$ SOC, MB-C was low while the microbes showed a high demand for C (Fig. 2) but simultaneously high C losses per unit biomass (Fig. 4), indicating that a large proportion of the ingested $\mathrm{C}$ was lost through respiration and could not be converted to microbial biomass. The apparent inability of the microbes to assimilate more $\mathrm{C}$ into biomass likely results from high microbial investments for resource acquisition in the resourcepoor soils that trade-off against microbial growth (Malik et al. 2019; Ramin and Allison 2019). These processes likely constrain the rates of $\mathrm{C}$ accrual in soil.

Generally, rates of $\mathrm{C}$ accrual from microbial biomass via necromass into SOC are not constant, but depend on the $\mathrm{C}$ saturation status of the soil matrix, which is a function of clay content (Frouz 2017; Stewart et al. 2007). Rates of C accrual decrease as soils approach C saturation (Kimetu et al. 2009; Stewart et al. 2009), but this does not necessarily equate to an increase of $\mathrm{C}$ accrual in soils far from $\mathrm{C}$ saturation. Instead, empirical measurements of $\mathrm{C}$ sequestration in post-mining chronosequences show a hyperbolic function with reduced rates of $\mathrm{C}$ and $\mathrm{N}$ accrual in both soils close to and far from C saturation (Bartuska and Frouz 2015; Frouz 2017). Assuming that the proper functioning of a soil is maintained by mineralisation of $\mathrm{C}$ and nutrients from $\mathrm{SOM}$, a minimum amount of SOM would be required for the necessary feedback processes to work. In agreement, Frouz (2017) concluded from empirical measurements of changes in SOC of chronosequence soils over time that a 'soil that has already accumulated some $\mathrm{C}$ will have a greater ability to accumulate additional C'. Given that the conversion rates of $\mathrm{C}$ into microbial biomass via microbial necromass directly feed back on the formation of SOC (Buchkowski et al. 2019), reduced rates of $\mathrm{C}$ accrual in soils far from C saturation (Bartuska and Frouz 2015; Frouz 2017) could be explained by increased microbial metabolic expenditures due to stoichiometric mismatch.

We infer that increasing SOC above the critical $1 \%$ SOC value transitioned the microbes into a new state where incorporation of $\mathrm{C}$ into biomass was more efficient (Fig. 4), as demonstrated by the parallel shifts in microbial stoichiometry and $\mathrm{qCO}_{2}$. This result is in line with previous studies which showed that decreases in the ratio of soil $\mathrm{C}$ to the next growthlimiting nutrient $(\mathrm{C}: \mathrm{X})$ lead to decreases in $\mathrm{qCO}_{2}$ (Hartman and Richardson 2013; Keiblinger et al. 2010; Spohn 2015; Spohn and Chodak 2015), demonstrating the coupling of nutrient limitation to $\mathrm{qCO}_{2}$ and nutrient-use efficiency. The rapid decrease in $\mathrm{qCO}_{2}$ in the chronosequence soils on approach to the critical value again indicates that microbes were out of stoichiometric equilibrium but moved quickly into a more nutrient-efficient stoichiometric state once soil nutrient content exceeded the critical value of $1 \%$ SOC. Correspondingly, Insam and Domsch (1988) on the study of forest restoration in post open-cast mining land reported a dramatic decrease of $\mathrm{qCO}_{2}$ once soil nutrient content exceeded $1 \%$ SOC, demonstrating that this observation is not only limited to agricultural soils.

\section{Microbial stoichiometric transitions occur at different critical values for different nutrients}

Our data do not only indicate a shift in stoichiometric state due to the crossing of a critical threshold level of SOM but also indicate that these microbial stoichiometric transitions occur at different critical values for different nutrients. $\mathrm{N}_{\text {tot }}$ was highly correlated to SOC (Fig. S4); therefore, a similar pattern towards increasing microbial $\mathrm{N}$ limitation was observed when MB-N was described as a function of soil $\mathrm{N}_{\text {tot }}$ (Fig. 3). The shift in MB-N occurred at $32 \mathrm{mmol} \mathrm{kg}^{-1}$ soil $\mathrm{N}_{\text {tot }}$. Soils with this concentration of total $\mathrm{N}$ contained approximately $400 \mathrm{mmol} \mathrm{kg}^{-1}$ SOC ( 0.5\% SOC; Fig. S4). Whereas the shift in $\mathrm{C}$ accrual rate occurred at $1 \%$ SOC (Fig. 1), meaning that the shift towards microbial $\mathrm{N}$ limitation (at $\sim 0.5 \% \mathrm{SOC}$ ) commenced at an earlier critical value of SOC.

Furthermore, shifts in microbial $\mathrm{N}$ accrual show that stoichiometric transitions were not smooth, but preceded a phase of high variability between 30 and $60 \mathrm{mmol} \mathrm{kg}^{-1} \mathrm{~N}_{\text {tot }}(0.04$ $\left.0.08 \% \mathrm{~N}_{\mathrm{tot}}\right)$. This high variation has been observed on the approach to a tipping point, which can be indicative of a system entering a critical state (Clements and Ozgul 2018). According to Scheffer et al. (2012), a decisive prerequisite for a tipping point is a positive feedback which drives the change to an alternative state after exceeding a threshold. Thus, once a critical level of $\mathrm{N}_{\text {tot }}$ (and SOC) was reached (Fig. 2), the more efficient incorporation of $\mathrm{C}$ into the microbial community (as confirmed by $\mathrm{qCO}_{2}$ ) generates a positive feedback which would be the prerequisite of a more efficient accrual of SOM from necromass (Ma et al. 2018).

\section{Towards a quantitative framework for SOC targets}

Our results show that by increasing SOM the microbial community shifted from an unstable, metabolic inefficient state (away from stoichiometric equilibrium) to a stable, more nutrient-efficient state on the crossing of a critical soil organic $\mathrm{C}$ content of $1 \%$. The concept that soil functions are dependent on critical values of SOM has been previously explored, in particular the effect of a $1 \%$ SOC critical value on crop yield and SOM decomposition rates in agricultural soils (Aune and Lal 1997; Loveland and Webb 2003). Considering the persistence of SOM as an ecosystem property (Schmidt et al. 2011), where the proper functioning of a soil is maintained by mineralisation of $\mathrm{C}$ and nutrients from SOM, a minimum amount of SOM appears essential for the necessary feedback processes to operate. Still, threshold ratios and nutrient limitations are most likely site-specific, depending on 
parent soil material and climatic constraints. It is important to note that the arable soils of the chronosequence did not acquire SOC in excess of $1 \%$ even 52 years after soil reclamation. Thus, the consequence of a threshold model for SOM accumulation in soil is that soils will remain in the inefficient state unless the critical tipping point is reached. This may well explain the repeated failure of arable field soils in becoming a stable C sink (Minasny et al. 2017; Schulp et al. 2008). Current meta-analyses suffer from the underrepresentation of agricultural soils, which are known for having the lowest $\mathrm{C}$ contents (Guo and Gifford 2002). Our data further indicate that it is crucial to compare soils of similar origin in order to detect clear patterns that help to explain stoichiometric variability. Our data are a first step towards establishing a quantitative framework for SOC targets that, along with agricultural intensification, support sustainable feedback mechanisms for the accrual of $\mathrm{C}$ in soils.

\section{Conclusion}

Overall, our combined results show that by increasing SOM the microbial community shifted from an unstable, metabolic inefficient state (away from stoichiometric equilibrium) to a stable, more nutrient-efficient state on the crossing of a critical soil organic $\mathrm{C}$ content of $1 \%$. Microorganisms in the young chronosequence soils, where stoichiometric imbalance was greatest, persisted in a nutrient-inefficient state with high $\mathrm{C}$ demand but low acquisition of biomass $\mathrm{C}$. When SOC increased above a critical value of $1 \%$ SOC, soils entered into an alternative stoichiometrically stable state where microbial $\mathrm{C}$ acquisition was more efficient. Similar mechanisms may underly the functioning of all natural and managed soil systems, but threshold ratios and nutrient limitations will be likely site-specific, depending on parent soil material and climatic constraints. Agricultural soils have the lowest $\mathrm{C}$ stocks; therefore, efforts to improve this may be fruitless if soils are still below a critical threshold value, even if $\mathrm{C}$ inputs are increased. A better understanding of critical elemental threshold ratios of soil microbial biomass may ultimately lead to an improved management of the processes governing the build-up of organic matter in soil.

Supplementary Information The online version contains supplementary material available at https://doi.org/10.1007/s00374-020-01532-2.

Acknowledgements The authors thank the INPLAMINT project team, especially Rüdiger Reichel for planning and organising the soil sampling campaign, and Nicolas Brüggemann for leading the consortium and his comments on the results, especially the breakpoint analysis. We further thank Gregor Esser and Ernst-Michael Ortmann of the 'Forschungsstelle Rekultivierung' for their logistic support in selecting the chronosequence sites and providing information on fertilisation history. Special thanks to colleagues Irene Brockhaus, Anna Herzog and Conny Thielen for help in soil analyses, and Christoph Rosinger, Anna Maria Fiore-Donno and Lioba Rüger for their valuable comments on the manuscript.

Funding Open Access funding enabled and organized by Projekt DEAL. The project was funded by the German Federal Ministry of Education and Research (BMBF) as part of the BonaRes initiative, in the project INPLAMINT: 'Increasing agricultural nutrient-use efficiency by optimizing plant-soil-microorganism interactions' (BMBF-FKZ 031B0508F).

Open Access This article is licensed under a Creative Commons Attribution 4.0 International License, which permits use, sharing, adaptation, distribution and reproduction in any medium or format, as long as you give appropriate credit to the original author(s) and the source, provide a link to the Creative Commons licence, and indicate if changes were made. The images or other third party material in this article are included in the article's Creative Commons licence, unless indicated otherwise in a credit line to the material. If material is not included in the article's Creative Commons licence and your intended use is not permitted by statutory regulation or exceeds the permitted use, you will need to obtain permission directly from the copyright holder. To view a copy of this licence, visit http://creativecommons.org/licenses/by/4.0/.

\section{References}

Allison SD, Vitousek PM (2005) Responses of extracellular enzymes to simple and complex nutrient inputs. Soil Biol Biochem 37:937-944. https://doi.org/10.1016/j.soilbio.2004.09.014

Anderson T-H, Domsch K (1985a) Determination of ecophysiological maintenance carbon requirements of soil microorganisms in a dormant state. Biol Fertil Soils 1:81-89

Anderson T-H, Domsch KH (1985b) Maintenance carbon requirements of actively-metabolizing microbial populations under in situ conditions. Soil Biol Biochem 17:197-203. https://doi.org/10.1016/00380717(85)90115-4

Anderson T-H, Domsch KH (1989) Ratios of microbial biomass carbon to total organic carbon in arable soils. Soil Biol Biochem 21:471479. https://doi.org/10.1016/0038-0717(89)90117-X

Anderson T-H, Domsch KH (2010) Soil microbial biomass: the ecophysiological approach. Soil Biol Biochem 42:2039-2043. https:// doi.org/10.1016/j.soilbio.2010.06.026

Aune J, Lal R (1997) Agricultural productivity in the tropics and critical limits of properties of Oxisols, Ultisols, and Alfisols. Tropical agriculture (Trinidad and Tobago) 74:96-103

Bartuska M, Frouz J (2015) Carbon accumulation and changes in soil chemistry in reclaimed open-cast coal mining heaps near Sokolov using repeated measurement of chronosequence sites. Eur J Soil Sci 66:104-111. https://doi.org/10.1111/ejss. 12185

Blagodatskaya E, Kuzyakov Y (2013) Active microorganisms in soil: critical review of estimation criteria and approaches. Soil Biol Biochem 67:192-211. https://doi.org/10.1016/j.soilbio.2013.08.024

Blagodatsky SA, Richter O (1998) Microbial growth in soil and nitrogen turnover: a theoretical model considering the activity state of microorganisms. Soil Biol Biochem 30:1743-1755. https://doi.org/10. 1016/S0038-0717(98)00028-5

Buchkowski RW, Shaw AN, Sihi D, Smith GR, Keiser AD (2019) Constraining carbon and nutrient flows in soil with ecological stoichiometry. Front Ecol Evol 7. https://doi.org/10.3389/fevo.2019. 00382 
Chabbi A, Lehmann J, Ciais P, Loescher HW, Cotrufo MF, Don A, SanClements M, Schipper L, Six J, Smith P, Rumpel C (2017) Aligning agriculture and climate policy. Nat Clim Chang 7:307309. https://doi.org/10.1038/nclimate3286

Chenu C, Stotzky G (2002) Interactions between microorganisms and soil particles: an overview. In: Huang PM, Bollag J-M, Senesi N (Eds) Interactions between soil particles and microorganisms - impact on the terrestrial ecosystems, IUPAC series of Applied Chemistry. John Wiley and Sons, Chichester, UK, pp 3-40

Clausing S, Pena R, Song B, Müller K, Mayer-Gruner P, Marhan S, Grafe M, Schulz S, Krüger J, Lang F, Schloter M, Kandeler E, Polle A (2020) Carbohydrate depletion in roots impedes phosphorus nutrition in young forest trees. New Phytol n/a. https://doi.org/10.1111/ nph. 17058

Clements CF, Ozgul A (2018) Indicators of transitions in biological systems. Ecol Lett 21:905-919. https://doi.org/10.1111/ele.12948

Cleveland CC, Liptzin D (2007) C:N:P stoichiometry in soil: is there a "Redfield ratio" for the microbial biomass? Biogeochemistry 85: 235-252. https://doi.org/10.1007/s10533-007-9132-0

Demoling F, Figueroa D, Baath E (2007) Comparison of factors limiting bacterial growth in different soils. Soil Biol Biochem 39:24852495. https://doi.org/10.1016/j.soilbio.2007.05.002

Dumbeck G (1992) Bodenkundliche Aspekte bei der landwirtschaftlichen Rekultivierung im rheinischen Braunkohlenrevier. Braunkohle 44:8-11

Dworschak U, Rose U (2014) Das Rheinische Braunkohlenrevier. In: Handbuch Naturschutz und Landschaftspflege. Wiley and Sons, New York, pp 1-23

Ehlers K, Bakken LR, Frostegård Å, Frossard E, Bünemann EK (2010) Phosphorus limitation in a Ferralsol: impact on microbial activity and cell internal P pools. Soil Biol Biochem 42:558-566. https://doi. org/10.1016/j.soilbio.2009.11.025

Fang Y, Singh BP, Collins D, Armstrong R, Van Zwieten L, Tavakkoli E (2020) Nutrient stoichiometry and labile carbon content of organic amendments control microbial biomass and carbon-use efficiency in a poorly structured sodic-subsoil. Biol Fertil Soils 56:219-233. https://doi.org/10.1007/s00374-019-01413-3

Fanin N, Fromin N, Barantal S, Hättenschwiler S (2017) Stoichiometric plasticity of microbial communities is similar between litter and soil in a tropical rainforest. Sci Rep 7:12498. https://doi.org/10.1038/ s41598-017-12609-8

Fanin N, Fromin N, Buatois B, Hättenschwiler S (2013) An experimental test of the hypothesis of non-homeostatic consumer stoichiometry in a plant litter-microbe system. Ecol Lett 16:764-772. https://doi.org/ 10.1111/ele. 12108

Farrell M, Prendergast-Miller M, Jones DL, Hill PW, Condron LM (2014) Soil microbial organic nitrogen uptake is regulated by carbon availability. Soil Biol Biochem 77:261-267. https://doi.org/10. 1016/j.soilbio.2014.07.003

Frouz J (2017) Effects of soil development time and litter quality on soil carbon sequestration: assessing soil carbon saturation with a field transplant experiment along a post-mining chronosequence. Land Degrad Dev 28:664-672. https://doi.org/10.1002/ldr.2580

Griffiths B, Spilles A, Bonkowski M (2012) C:N:P stoichiometry and nutrient limitation of the soil microbial biomass in a grazed grassland site under experimental P limitation or excess. Ecol Process 1:6

Guo LB, Gifford RM (2002) Soil carbon stocks and land use change: a meta analysis. Glob Chang Biol 8:345-360. https://doi.org/10.1046/ j.1354-1013.2002.00486.x

Hartman WH, Richardson CJ (2013) Differential nutrient limitation of soil microbial biomass and metabolic quotients $\left(\mathrm{qCO}_{2}\right)$ : is there a biological stoichiometry of soil microbes? PLoS One 8:e57127. https://doi.org/10.1371/journal.pone.0057127

Hessen DO, Agren GI, Anderson TR, Elser JJ, De Ruiter PC (2004) Carbon, sequestration in ecosystems: the role of stoichiometry. Ecology 85:1179-1192
Insam H, Domsch KH (1988) Relationship between soil organic carbon and microbial biomass on chronosequences of reclamation sites. Microb Ecol 15:177-188. https://doi.org/10.1007/BF02011711

Insam H, Haselwandter K (1989) Metabolic quotient of the soil microflora in relation to plant succession. Oecologia 79:174-178. https:// doi.org/10.1007/BF00388474

Insam H, Hutchinson TC, Reber HH (1996) Effects of heavy metal stress on the metabolic quotient of the soil microflora. Soil Biol Biochem 28:691-694. https://doi.org/10.1016/0038-0717(95)00182-4

Joergensen RG (1996) The fumigation extraction method to estimate soil microbial biomass: calibration of the kEC-factor. Soil Biol Biochem 28:25-31

Joergensen RG, Wichern F (2018) Alive and kicking: why dormant soil microorganisms matter. Soil Biol Biochem 116:419-430. https:// doi.org/10.1016/j.soilbio.2017.10.022

Kaiser EA (1994) Significance of microbial biomass for carbon and nitrogen mineralization in soil. Zeitschrift fur Pflanzenernahrung und Bodenkunde 157:271-278

Kallenbach C, Grandy AS (2011) Controls over soil microbial biomass responses to carbon amendments in agricultural systems: a metaanalysis. Agric Ecosyst Environ 144:241-252

Kallenbach C, Grandy AS, Frey S, Diefendorf A (2015) Microbial physiology and necromass regulate agricultural soil carbon accumulation. Soil Biol Biochem 91:279-290

Kallenbach CM, Frey SD, Grandy AS (2016) Direct evidence for microbial-derived soil organic matter formation and its ecophysiological controls. Nat Commun 7:13630. https://doi.org/10.1038/ ncomms13630. https://www.nature.com/articles/ncomms13630\# supplementary-information

Kamble PN, Bååth E (2014) Induced N-limitation of bacterial growth in soil: effect of carbon loading and N status in soil. Soil Biol Biochem 74:11-20. https://doi.org/10.1016/j.soilbio.2014.02.015

Keiblinger KM, Hall EK, Wanek W, Szukics U, Hämmerle I, Ellersdorfer G, Böck S, Strauss J, Sterflinger K, Richter A, ZechmeisterBoltenstern S (2010) The effect of resource quantity and resource stoichiometry on microbial carbon-use-efficiency. FEMS Microbiol Ecol 73:430-440. https://doi.org/10.1111/j.1574-6941.2010.00912.

Khan KS, Joergensen RG (2019) Stoichiometry of the soil microbial biomass in response to amendments with varying $\mathrm{C} / \mathrm{N} / \mathrm{P} / \mathrm{S}$ ratios. Biol Fertil Soils 55:265-274. https://doi.org/10.1007/s00374-01901346-x

Kirkby CA, Richardson AE, Wade LJ, Batten GD, Blanchard C, Kirkegaard JA (2013) Carbon-nutrient stoichiometry to increase soil carbon sequestration. Soil Biol Biochem 60:77-86. https://doi.org/ 10.1016/j.soilbio.2013.01.011

Kimetu JM, Lehmann J, Kinyangi JM, Cheng CH, Thies J, Mugendi DN, Pell A (2009) Soil organic C stabilization and thresholds in C saturation. Soil Biol Biochem 41:2100-2104. https://doi.org/10.1016/j. soilbio.2009.07.022

Kögel-Knabner I, Guggenberger G, Kleber M, Kandeler E, Kalbitz K, Scheu S, Eusterhues K, Leinweber P (2008) Organo-mineral associations in temperate soils: integrating biology, mineralogy, and organic matter chemistry. J Plant Nutr Soil Sci 171:61-82. https://doi. org/10.1002/jpln.200700048

Kouno K, Tuchiya Y, Ando T (1995) Measurement of soil microbial biomass phosphorus by an anion exchange membrane method. Soil Biol Biochem 27:1353-1357

Kuzyakov Y, Blagodatskaya E (2015) Microbial hotspots and hot moments in soil: concept \& review. Soil Biol Biochem 83:184-199. https://doi.org/10.1016/j.soilbio.2015.01.025

Li Y, Wu J, Liu S, Shen J, Huang D, Su Y, Wei W, Syers JK (2012) Is the $\mathrm{C}: \mathrm{N}: \mathrm{P}$ stoichiometry in soil and soil microbial biomass related to the landscape and land use in southern subtropical China? Global Biogeochemical Cycles 26. https://doi.org/10.1029/2012GB004399 
Liang C, Schimel JP, Jastrow JD (2017) The importance of anabolism in microbial control over soil carbon storage. Nat Microbiol 2:17105. https://doi.org/10.1038/MBNrobiol.2017.105

Liu X, Zhang X, Wang Y, Sui Y, Zhang S, Herbert S, Ding G (2010) Soil degradation: a problem threatening the sustainable development of agriculture in Northeast China. Plant Soil Environ 56:87-97

Loveland P, Webb J (2003) Is there a critical level of organic matter in the agricultural soils of temperate regions: a review. Soil Till Res 70:118. https://doi.org/10.1016/S0167-1987(02)00139-3

Lucas M, Schlüter S, Vogel H-J, Vetterlein D (2019) Soil structure formation along an agricultural chronosequence. Geoderma 350:6172. https://doi.org/10.1016/j.geoderma.2019.04.041

Ma B, Zhou X, Zhang Q, Qin M, Hu L, Yang K, Xie Z, Ma W, Chen B, Feng H, Liu Y, Du G, Ma X, Roux XL (2019) How do soil microorganisms respond to N, P and NP additions? Application of the ecological framework of (co-)limitation by multiple resources. J Ecol 107:2329-2345. https://doi.org/10.1111/1365-2745.13179

Ma T, Zhu S, Wang Z, Chen D, Dai G, Feng B, Su X, Hu H, Li K, Han W, Liang C, Bai Y, Feng X (2018) Divergent accumulation of microbial necromass and plant lignin components in grassland soils. Nat Commun 9:3480. https://doi.org/10.1038/s41467-018-05891-1

Manzoni S, Porporato A (2009) Soil carbon and nitrogen mineralization: theory and models across scales. Soil Biol Biochem 41:1355-1379. https://doi.org/10.1016/j.soilbio.2009.02.031

Malik AA, Puissant J, Goodall T, Allison SD, Griffiths RI (2019) Soil microbial communities with greater investment in resource acquisition have lower growth yield. Soil Biol Biochem 132:36-39. https:// doi.org/10.1016/j.soilbio.2019.01.025

Marklein AR, Houlton BZ (2012) Nitrogen inputs accelerate phosphorus cycling rates across a wide variety of terrestrial ecosystems. New Phytol 193:696-704. https://doi.org/10.1111/j.1469-8137.2011. 03967.x

Miltner A, Kindler R, Knicker H, Richnow HH, Kästner M (2009) Fate of microbial biomass-derived amino acids in soil and their contribution to soil organic matter. Org Geochem 40:978-985. https://doi.org/10. 1016/j.orggeochem.2009.06.008

Miltner A, Bombach P, Schmidt-Brücken B, Kästner M (2012) SOM genesis: microbial biomass as a significant source. Biogeochemistry 111:41-55. https://doi.org/10.1007/s10533-0119658-z

Minasny B, Malone BP, McBratney AB, Angers DA, Arrouays D, Chambers A, Chaplot V, Chen Z-S, Cheng K, Das BS, Field DJ, Gimona A, Hedley CB, Hong SY, Mandal B, Marchant BP, Martin M, McConkey BG, Mulder VL, O'Rourke S, Richer-de-Forges AC, Odeh I, Padarian J, Paustian K, Pan G, Poggio L, Savin I, Stolbovoy V, Stockmann U, Sulaeman Y, Tsui C-C, Vågen T-G, van Wesemael B, Winowiecki L (2017) Soil carbon 4 per mille. Geoderma 292:59-86. https://doi.org/10.1016/j.geoderma.2017.01. 002

Mooshammer M, Wanek W, Zechmeister-Boltenstern S, Richter A (2014) Stoichiometric imbalances between terrestrial decomposer communities and their resources: mechanisms and implications of microbial adaptations to their resources. Front Microbiol 5. https:// doi.org/10.3389/fmicb.2014.00022

Muggeo VMR (2008) Segmented: an R package to fit regression models with broken-line relationships. R News 8:20-25 URL https://cran.rproject.org/doc/Rnews/

Mulder C, Ahrestani FS, Bahn M, Bohan DA, Bonkowski M, Griffiths BS, Guicharnaud RA, Kattge J, Krogh PH, Lavorel S, Lewis OT, Mancinelli G, Naeem S, Peñuelas J, Poorter H, Reich PB, Rossi L, Rusch GM, Sardans J, Wright IJ (2013) Connecting the green and brown worlds: elemental factors and trait-driven predictability of ecological networks. Adv Ecol Res 49:70-175. https://doi.org/10. 1016/B978-0-12-420002-9.00002-0
Murphy J, Riley JP (1962) A modified single solution method for the determination of phosphate in natural waters. Anal Chim Acta 27: $31-36$

Myers RG, Thien SJ, Pierzynski GM (1999) Using an ion sink to extract microbial phosphorus from soil. Soil Sci Soc Am J 63:1229-1237. https://doi.org/10.2136/sssaj1999.6351229x

Nannipieri P, Ascher J, Ceccherini MT, Landi L, Pietramellara G, Renella G (2003) Microbial diversity and soil functions. Eur J Soil Sci 54: 655-670. https://doi.org/10.1046/j.1351-0754.2003.0556.x

Nelson DW, Sommers LE (1996) Total carbon, organic carbon, and organic matter. In: Sparks DL, Page AL, Helmke PA, Loeppert RH, Nelson DW, Sommers LE (Eds) Methods of soil analysis: Part 3 Chemical Methods, 5.3. SSSA Book Series. Soil Science Society of America, Madison, pp 961-1010. https://doi.org/10. 2136/sssabookser5.3.c34

Odum EP (1985) Trends expected in stressed ecosystems. BioScience 35: 419-422. https://doi.org/10.2307/1310021

Oldfield EE, Bradford MA, Wood SA (2019) Global meta-analysis of the relationship between soil organic matter and crop yields. Soil 5:1532. https://doi.org/10.5194/soil-5-15-2019

Panettieri M, Knicker H, Murillo JM, Madejón E, Hatcher PG (2014) Soil organic matter degradation in an agricultural chronosequence under different tillage regimes evaluated by organic matter pools, enzymatic activities and CPMAS ${ }^{13} \mathrm{C}$ NMR. Soil Biol Biochem 78:170 181. https://doi.org/10.1016/j.soilbio.2014.07.021

Paustian K, Babcock B, Hatfield J, Kling C, Lal R, McCarl B, McLaughlin S, Mosier A, Post W, Robertson GP, Rosenberg N, Rosenzweig C, Schlesinger W, Zilberman D, Manale A (2004) Climate change and greenhouse gas mitigation: challenges and opportunities for agriculture. CAST Task Force Report 141

Pihlap E, Vuko M, Lucas M, Steffens M, Schloter M, Vetterlein D, Endenich M, Kögel-Knabner I (2019) Initial soil formation in an agriculturally reclaimed open-cast mining area - the role of management and loess parent material. Soil Till Res 191:224-237. https:// doi.org/10.1016/j.still.2019.03.023

Pickett STA (1989) Space-for-time substitution as an alternative to longterm studies. In: Likens GE (ed) Long-term studies in ecology: approaches and alternatives. Springer-Verlag, New York

Poulton P, Johnston J, Macdonald A, White R, Powlson D (2018) Major limitations to achieving " 4 per 1000 " increases in soil organic carbon stock in temperate regions: evidence from long-term experiments at Rothamsted Research, United Kingdom. Glob Chang Biol 24:2563-2584. https://doi.org/10.1111/gcb.14066

$\mathrm{R}$ Core Team (2018): A language and environment for statistical computing http://www.R-project.org/

Ramin KI, Allison SD (2019) Bacterial tradeoffs in growth rate and extracellular enzymes. Front Microbiol 10. https://doi.org/10.3389/ fmicb.2019.02956

Roy J, Reichel R, Bruggemann N, Hempel S, Rillig MC (2017) Succession of arbuscular mycorrhizal fungi along a 52-year agricultural recultivation chronosequence. FEMS Microbiol Ecol 93. https://doi.org/10.1093/femsec/fix 102

Sakamoto K, Oba Y (1994) Effect of fungal to bacterial biomass ratio on the relationship between $\mathrm{CO}_{2}$ evolution and total soil microbial biomass. Biol Fertil Soils 17:39-44

Sanderman J, Creamer C, Baisden WT, Farrell M, Fallon S (2017) Greater soil carbon stocks and faster turnover rates with increasing agricultural productivity. Soil 3:1-16. https://doi.org/10.5194/soil$3-1-2017$

Sarkar D (2008) Lattice: multivariate data visualization with R. Springer Science \& Business Media, Berlin

Sarkar D, Andrews F (2019) Extra graphical utilities based on lattice. Springer Science \& Business Media, Berlin http://latticeextra.rforge.r-project.org/

Scheffer M, Carpenter SR, Lenton TM, Bascompte J, Brock W, Dakos V, van de Koppel J, van de Leemput IA, Levin SA, van Nes EH, 
Pascual M, Vandermeer J (2012) Anticipating critical transitions. Science 338:344-348

Scheu S (1992) Automated measurement of the respiratory response of soil microcompartments: active microbial biomass in earthworm faeces. Soil Biol Biochem 24:1113-1118. https://doi.org/10.1016/ 0038-0717(92)90061-2

Schimel J, Weintraub MN (2003) The implications of exoenzyme activity on microbial carbon and nitrogen limitation in soil: a theoretical model. Soil Biol Biochem 35:549-563. https://doi.org/10.1016/ s0038-0717(03)00015-4

Schmidt MWI, Torn MS, Abiven S, Dittmar T, Guggenberger G, Janssens IA, Kleber M, Kögel-Knabner I, Lehmann J, Manning DAC, Nannipieri P, Rasse DP, Weiner S, Trumbore SE (2011) Persistence of soil organic matter as an ecosystem property. Nature 478:49-56. https://doi.org/10.1038/nature 10386

Schüller H (1969) Die CAL-Methode, eine neue Methode zur Bestimmung des pflanzenverfügbaren Phosphates in Böden. Z. Pflanzenernährg Bodenk 123:48-63

Schulp CJE, Nabuurs G-J, Verburg PH (2008) Future carbon sequestration in Europe - effects of land use change. Agric Ecosyst Environ 127:251-264. https://doi.org/10.1016/j.agee.2008.04.010

Scott T, Cotner J, LaPara T (2012) Variable stoichiometry and homeostatic regulation of bacterial biomass elemental composition. Front Microbiol 3. https://doi.org/10.3389/fmicb.2012.00042

Singh BP, Setia R, Wiesmeier M, Kunhikrishnan A (2018) Chapter 7 agricultural management practices and soil organic carbon storage. In: Singh BK (Ed) Soil carbon storage. Academic Press, London, pp 207-244. https://doi.org/10.1016/B978-0-12-812766-7.00007-X

Sinsabaugh RL, Hill BH, Shah JJF (2009) Ecoenzymatic stoichiometry of microbial organic nutrient acquisition in soil and sediment. Nature 462:795-U117. https://doi.org/10.1038/nature08632

Sinsabaugh RL, Manzoni S, Moorhead DL, Richter A (2013) Carbon use efficiency of microbial communities: stoichiometry, methodology and modelling. Ecol Lett 16:930-939

Sinsabaugh RL, Moorhead DL (1994) Resource allocation to extracellular enzyme production: a model for nitrogen and phosphorus control of litter decomposition. Soil Biol Biochem 26:1305-1311. https:// doi.org/10.1016/0038-0717(94)90211-9

Sinsabaugh RL, Turner BL, Talbot JM, Waring BG, Powers JS, Kuske CR, Moorhead DL, Shah JJF (2016) Stoichiometry of microbial carbon use efficiency in soils. Ecol Monogr 86:172-189. https:// doi.org/10.1890/15-2110.1

Spohn M (2015) Microbial respiration per unit microbial biomass depends on litter layer carbon-to-nitrogen ratio. Biogeosciences 12: 817-823. https://doi.org/10.5194/bg-12-817-2015

Spohn M (2016) Element cycling as driven by stoichiometric homeostasis of soil microorganisms. Basic Appl Ecol 17:471-478. https://doi. org/10.1016/j.baae.2016.05.003

Spohn M, Chodak M (2015) Microbial respiration per unit biomass increases with carbon-to-nutrient ratios in forest soils. Soil Biol Biochem 81:128-133. https://doi.org/10.1016/j.soilbio.2014.11.008
Stewart CE, Paustian K, Conant RT, Plante AF, Six J (2007) Soil carbon saturation: concept, evidence and evaluation. Biogeochemistry 86 : 19-31. https://doi.org/10.1007/s10533-007-9140-0

Stewart CE, Paustian K, Conant RT, Plante AF, Six J (2009) Soil carbon saturation: implications for measurable carbon pool dynamics in long-term incubations. Soil Biol Biochem 41:357-366. https://doi. org/10.1016/j.soilbio.2008.11.011

Traoré OYA, Kiba DI, Arnold MC, Fliessbach A, Oberholzer HR, Nacro HB, Lompo F, Oberson A, Frossard E, Bünemann EK (2015) Fertilization practices alter microbial nutrient limitations after alleviation of carbon limitation in a Ferric Acrisol. Biol Fertil Soils 52: 177-189. https://doi.org/10.1007/s00374-015-1061-9

Vance ED, Brookes PC, Jenkinson DS (1987) An extraction method for measuring soil microbial biomass C. Soil Biol Biochem 19:703707. https://doi.org/10.1016/0038-0717(87)90052-6

Walker LR, Wardle DA, Bardgett RD, Clarkson BD (2010) The use of chronosequences in studies of ecological succession and soil development. J Ecol 98:725-736. https://doi.org/10.1111/j.1365-2745. 2010.01664.x

Wickham H (2016) ggplot2: elegant graphics for data analysis. SpringerVerlag, New York

Wickham H, François R, Henry L, (2018) RStudio 2018. dplyr: a grammar of data manipulation. R Package Version 0.7. 6

Wickham H, Henry L (2018) tidyr: easily tidy data with "spread ()" and "gather ()" functions. R package version 0.8. 0. URL https://cran.Rproject.org/package=tidyr,

Wu J, Joergensen RG, Pommerening B, Chaussod R, Brookes PC (1990) Measurement of soil microbial biomass $\mathrm{C}$ by fumigation-extractionan automated procedure. Soil Biol Biochem 22:1167-1169. https:// doi.org/10.1016/0038-0717(90)90046-3

Xu X, Schimel JP, Janssens IA, Song X, Song C, Yu G, Sinsabaugh RL, Tang D, Zhang X, Thornton PE (2017) Global pattern and controls of soil microbial metabolic quotient. Ecol Monogr 87:429-441. https://doi.org/10.1002/ecm.1258

Xue H, Lan X, Liang H, Zhang Q (2019) Characteristics and environmental factors of stoichiometric homeostasis of soil microbial biomass carbon, nitrogen and phosphorus in China. Sustainability 11: 2804

Zechmeister-Boltenstern S, Keiblinger KM, Mooshammer M, Peñuelas J, Richter A, Sardans J, Wanek W (2015) The application of ecological stoichiometry to plant-microbial-soil organic matter transformations. Ecol Monogr 85:133-155. https://doi.org/10.1890/14-0777.1

Zhou H, Zhang D, Wang P, Liu X, Cheng K, Li L, Zheng J, Zhang X, Zheng J, Crowley D, van Zwieten L, Pan G (2017) Changes in microbial biomass and the metabolic quotient with biochar addition to agricultural soils: a meta-analysis. Agric Ecosyst Environ 239: 80-89. https://doi.org/10.1016/j.agee.2017.01.006

Publisher's note Springer Nature remains neutral with regard to jurisdictional claims in published maps and institutional affiliations. 